\title{
High-resolution studies on vegetation succession, hydrological variations, anthropogenic impact and genesis of a subrecent lake in southern Ecuador
}

\author{
Corinna Brunschön • Torsten Haberzettl • \\ Hermann Behling
}

Received: 9 June 2009/ Accepted: 9 November 2009/Published online: 20 January 2010

(C) The Author(s) 2010. This article is published with open access at Springerlink.com

\begin{abstract}
A lake sediment record from Laguna Campana at 2,488 $\mathrm{m}$ a.s.l. in the eastern Ecuadorian Andes allows the reconstruction of local environmental conditions over the past $\sim 500$ years. A high-resolution multi-proxy approach using pollen, spore, charcoal and XRF analyses provides information about lake genesis, hydrological variations and the development of the surrounding vegetation. Results suggest that Laguna Campana originated from a landslide, which are naturally common and anthropogenically promoted in the study area. Human activities, e.g. deforestation or slash and burn cultivation, impacted the local vegetation development and biodiversity during the recorded period. After a first dense layer of pioneer grasses developed on open soil around the small lake, successional stages of secondary upper mountain rainforest forest mainly composed of Alnus and Weinmannia were observed. The record shows no signs of dense forest regeneration but rather open vegetation with trees and a grassy understory. Especially since ca. A.D. 1980, the proportion of forest in the area was reduced, most probably by fire use for pastures, cultivation
\end{abstract}

Communicated by E.C. Grimm.

C. Brunschön $(\varangle) \cdot H$. Behling

Department of Palynology and Climate Dynamics, Albrechtvon-Haller Institute for Plant Sciences, University of Göttingen, Untere Karspüle 2, 37073 Göttingen, Germany

e-mail: Corinna.Brunschoen@biologie.uni-goettingen.de

T. Haberzettl

Department of Physical Geography, Institute of Geography, Friedrich-Schiller-University Jena, Löbdergraben 32, 07740 Jena, Germany and wood extraction. Hydrological variability was derived from differences in minerogenic input and variations in Botryococcus braunii and Sphagnum occurrence. After wettest conditions at the study site, probably triggering the landslide, humid conditions persisted until a time of drier conditions between A.D. 1900 and 1960. A subsequent return to wetter conditions was observed over the last decades. $\mathrm{XRF}$ analyses suggest an increase in deposition of atmospherically derived lead since the formation of the lake.

Keywords Multi-proxy · Pollen · Vegetation history · Anthropogenic impact · Lead · Hydrological variability . Ecuadorian Andes

\section{Introduction}

Tropical mountain regions, as occur in the eastern Andes of Ecuador, are emphasized as holding the world's most significant biodiversity hotspots (Barthlott et al. 2005). Different environmental conditions are responsible for this phenomenon. Among the triggers of biodiversity, for example the complex topography and highly varied climatic conditions can be specified for the Andean region. Additionally, the uplift of mountain chains causing an extensive evolutionary radiation should be considered in terms of species richness and biodiversity levels (Richter 2008). Hence, tropical mountain ecosystems and their origin play an important role in biodiversity research. However, palaeoecological records in mountain forests of the Andean region are thinly scattered not least because of the steep slopes and scarcity of natural archives (Bush et al. 2007). The first palynological studies in the eastern Ecuadorian Andes focusing on the Podocarpus National Park (PNP) and its megadiverse mountain ecosystems have been carried out 
recently (Beck et al. 2008a). Several palaeoecological analyses of sediment cores at high elevations up to 3,300 $\mathrm{m}$ a.s.l. were used to begin a comprehensive reconstruction of late Quaternary vegetation of the PNP (Brunschön and Behling 2009; Niemann and Behling 2008a, b; Niemann and Behling 2009, 2010; Niemann et al. 2009).

Within the South American countries Ecuador currently suffers from the highest deforestation rate of 198,000 ha year $^{-1}$ (FAO 2006). Already during pre-Columbian times a long-lasting deforestation in the mountain regions had contributed to the reduction of forest areas (Wunder 2000). Early human settlements were accompanied by land use for cultivation and pastures, converting natural landscapes into man-made environments on a large scale. During the most recent times agricultural colonization due to increasing population is further amplified by infrastructure improvements (Pohle 2008). Extensive road construction and other anthropogenic factors additionally promote wide-spread landslides in the Ecuadorian Andes, which are also naturally triggered, for example by unstable slopes and perhumid environmental conditions (Lozano et al. 2005). The landslides are assumed to play an important role in maintaining species diversity in tropical mountain forests (Guariguata 1990; Kessler 1999).

This study focuses on environmental and vegetation dynamics of mountain ecosystems in the area of the Podocarpus National Park. High-resolution multi-proxy palaeoecological analyses of the Laguna Campana sediment record (Fig. 1) are used to provide detailed insights into palaeoenvironmental variations. This will allow the identification of possible past human influences and their potential impacts on local vegetation and biodiversity.

\section{Study site}

Location

Laguna Campana $\left(04^{\circ} 01^{\prime} 28^{\prime \prime} \mathrm{S}, 79^{\circ} 10^{\prime} 40^{\prime \prime} \mathrm{W}\right)$ is located on the western slope of the Cordillera Real, an eastern Andean range of Southern Ecuador at an elevation of 2,488 m a.s.l. (Fig. 1). Nearby crests reach elevations of up to $\sim 3,100 \mathrm{~m}$. The study area is about $5 \mathrm{~km}$ southeast of the city of Loja (2,100 m a.s.1., Fig. 1) and $2 \mathrm{~km}$ west of the Podocarpus National Park (PNP), which is located between the provinces of Loja and Zamora-Chinchipe. The small village of Zamora Huayco Alto is situated west of Laguna Campana about $300 \mathrm{~m}$ downhill. Observations of surrounding geomorphologic structures suggest that Laguna Campana was probably formed by a landslide the age of which is, hitherto, unknown. Nowadays, the small lake neither has an inflow nor an outflow. It has a maximum water depth of $1.5 \mathrm{~m}$ and covers an area of about $1,500 \mathrm{~m}^{2}$.

Geomorphology and geology

The so called Girón-Cuenca and Huancabamba Andean depression region in the eastern Andean range of southern Ecuador and northern Peru $\left(2-6^{\circ} \mathrm{S}\right)$ is characterised by low elevations not exceeding 4,000 $\mathrm{m}$ a.s.l. (Richter and Moreira-Muñoz 2005). Volcanoes as well as glaciers are absent (Schubert and Clapperton 1990). Hence, volcanic contributions to the sediments of Laguna Campana are negligible. The area of the Andean depression, where the study site is located, consists of a complicated topography as a junction of mountain ranges culminates in the so called
Fig. 1 Map showing a the location of Ecuador in South America, $\mathbf{b}$ the Andes (shaded area) and the limits of the Podocarpus National Park and c a detailed sketch of the research area between the cities of Loja and Zamora. The study site Laguna Campana is located at $2488 \mathrm{~m}$ a.s.l. west of the northern Podocarpus National Park area

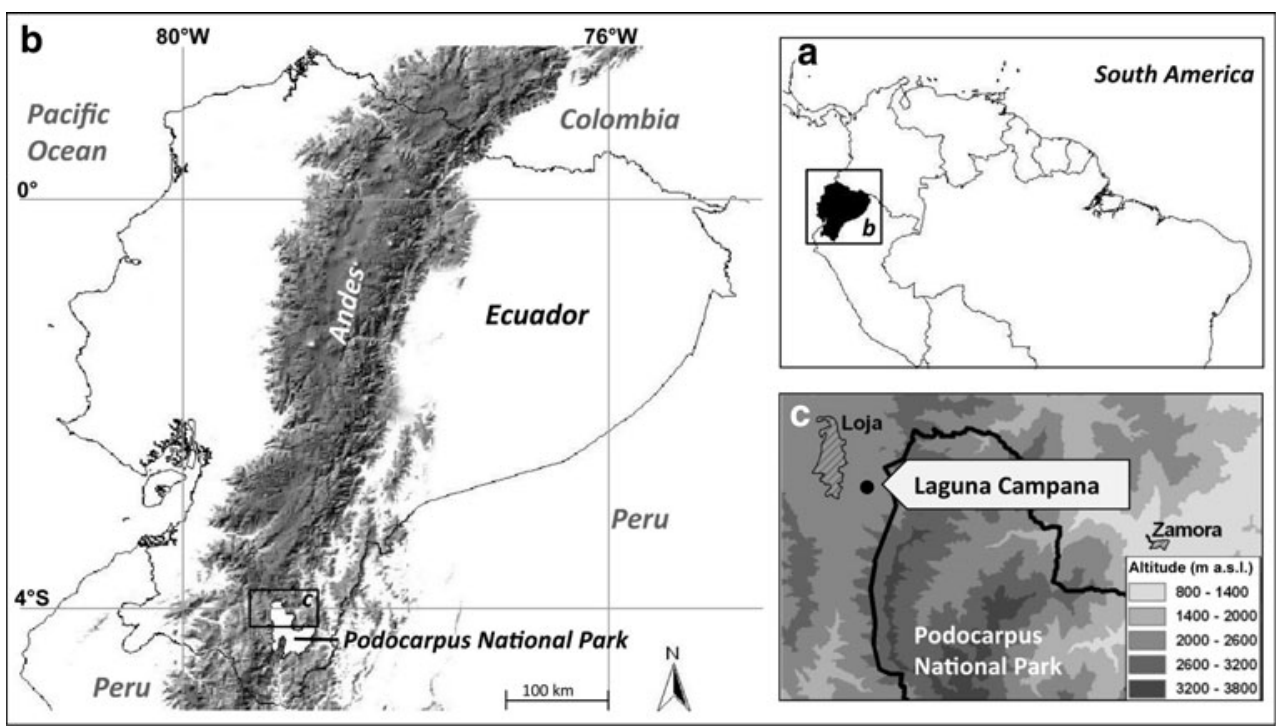




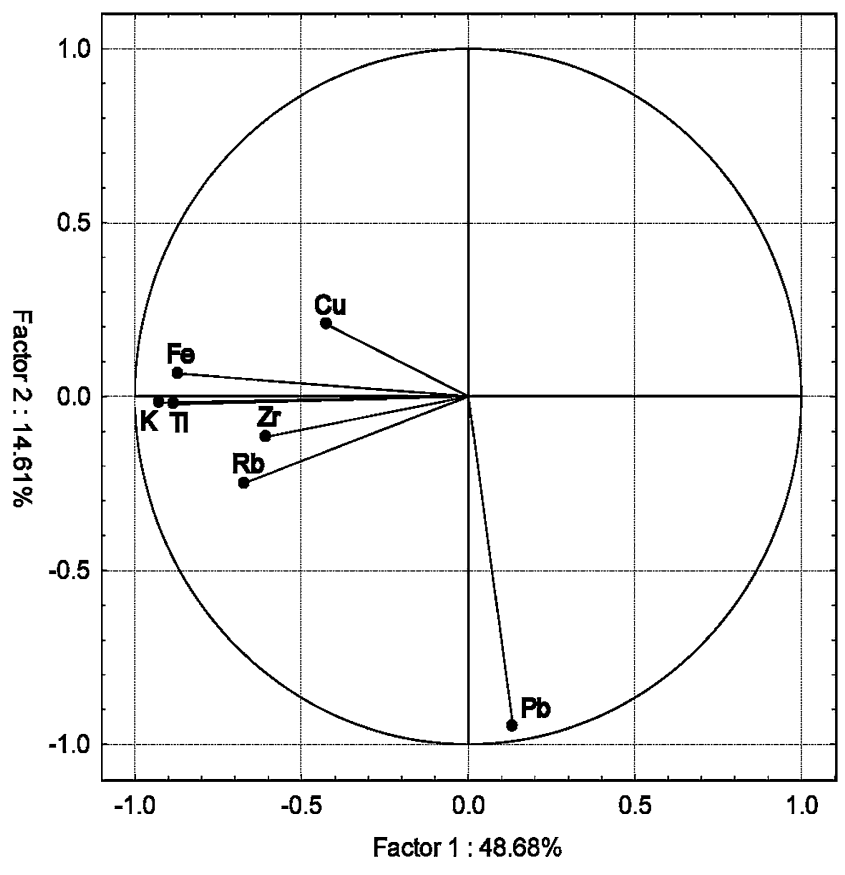

Fig. 2 Principle Component Analysis (PCA) of all elements showing an average above 100 pa (peak area)

"Nudo de Loja", from which Inter-Andean Sierras stretch in different directions dissected by valleys and basins (Beck et al. 2008b). The eastern Andean Cordillera is mainly made up of Paleozoic metamorphic rocks (Baldock 1982). Rocks around Loja consist of mica schists, gneisses and granites. The basin margins contain conglomerates of metamorphic debris and argillaceous sandstone in the Miocene layers, which promote landslides of water saturated soils (Sauer 1971). Landslides in the tropical mountain forests of Ecuador are mostly shallow soil removals. Often only O-horizons and upper parts of the A-horizons are displaced further downslope (Bussmann et al. 2008). Geomorphologic evidence for landslides can be observed all around the study site including Laguna Campana.

\section{Climate}

The climate of Ecuador including the study area is dominated by the tropical trade wind regime characterised by strong easterlies bringing moist air masses from the Amazon basin (Beck et al. 2008b). The Cordillera Real acts as a climatic divide separating moist conditions on the Amazon exposed eastern side from the (semi-) arid climate on the west (Emck 2007). East of the Cordillera, precipitation and humidity rise continuously to the crest regions. The western escarpment and the Inter-Andean zone belong to the greater lee of the Cordillera Real, where arid conditions start immediately behind the climate divide. Rainfall of $6,000 \mathrm{~mm} \mathrm{a}^{-1}$ at $3,100 \mathrm{~m}$ a.s.l. contrasts with the Inter-Andean basin, which receives generally less than
$1,000 \mathrm{~mm} \mathrm{a}^{-1}$ (Emck 2007; Bendix et al. 2008a). As Laguna Campana is located on the western slopes of Cordillera Real it faces the dry Inter-Andean basin (Fig. 1). Rainfall variability reveals a diurnal and seasonal pattern in the study area. Variations caused by ENSO (El NiñoSouthern Oscillation) do not have an influence as the region is sheltered from Pacific air masses by the mountain ranges (Bendix et al. 2008b).

Temperature varies according to the time of day and season. The austral winter is the wettest and coldest period of the year (Bendix et al. 2008a). Laguna Campana is situated between the so called "tierras templadas and frescas" (temperate and cool land), where soil temperature of ca. $15^{\circ} \mathrm{C}$ and $9-12$ humid months are observed. Measurements at Loja (2,160 m a.s.1., $2.5 \mathrm{~km}$ from Laguna Campana) indicate a mean annual precipitation of $922-947 \mathrm{~mm}$ and a mean annual temperature of $15.5^{\circ} \mathrm{C}$ (Richter and MoreiraMuñoz 2005; Günter et al. 2008).

\section{Modern vegetation}

The potential vegetation in the PNP area was described by Homeier et al. (2008) and citations therein (e.g. Lozano 2002; Aguirre et al. 2003; Richter 2003). Accordingly, five of the potential natural vegetation types describe the area surrounding Laguna Campana best: lower and upper mountain rainforest, interandean semideciduous forest, subpáramo and páramo. The study site and large areas in the provinces of Loja and Zamora-Chinchipe surrounding the PNP are degraded. The natural vegetation has been modified by anthropogenic activities such as road construction, deforestation, fire use and pastures.

Lower mountain rainforest (LMF) with a canopy height of $30 \mathrm{~m}$ is found at ca. 1,300-2,100 m a.s.l. on the eastern escarpment of the Cordillera Real. Characteristic species are among others Cyathea caracasana, Morus insignis, Piper sp., Mikania sp. and Heliocarpus americanus.

Laguna Campana is located in the potential vegetation type of upper mountain rainforest (UMF) between ca. 2,400-2,700 $\mathrm{m}$ a.s.l. on the western escarpment above Loja. The canopy attains heights of up to $20 \mathrm{~m}$. Some of the main key species are Hedyosmum racemosum, Weinmannia sp., Myrica pubescens, Myrsine andina, Prumnopitys montana, Clusia sp. and Cedrela montana. It was observed in the field that the vegetation in the area frequently burned, promoting sparse shrubland dominated by burnt Puya plants on open soils. Pinus is found in the surroundings. The UMF on the eastern escarpment (ca. 2,100-2,700 $\mathrm{m}$ a.s.1.) varies in species composition and reaches a canopy height of up to $25 \mathrm{~m}$. Some key species which differ from those of the western slope are, e.g. Ilex rimbachii, Purdiaea nutans, Macrocarpaea revoluta, Podocarpus oleifolius and Dioicodendron dioicum. 
At ca. 2,700-3,100 $\mathrm{m}$ a.s.l. on the eastern and western escarpment subpáramo vegetation is present, including a subtype of elfin forest forming the upper forest line ecotone. Canopy heights are 6-8 $\mathrm{m}$ and for the subpáramo a little less. Characteristic species are, e.g. Clethra ovalifolia, Gaultheria reticulata, Gaiadendron punctatum, Graffenrieda harlingii and Hesperomeles ferruginea.

Páramo (including shrub and herb páramo) is found above the upper forest line at ca. 3,100-3,600 m elevation. Páramo vegetation is characterised by a maximum height of $2 \mathrm{~m}$. Some key species are Puya eryngioides, Rhynchospora vulcani, Chusquea neurophylla, Monnina arbuscula and Valeriana microphylla.

South-west of the study site in the basin at ca. 1,400$2,400 \mathrm{~m}$ a.s.l. interandean semideciduous forest (SDF) is found. The canopy height reaches $15 \mathrm{~m}$, occasionally about $20 \mathrm{~m}$. Some indicator species are Ceiba insignis, Croton wagneri, Acacia macracantha, Anadenanthera colubrine and Dodonaea viscosa.

\section{Materials and methods}

For sediment sampling in the centre of Laguna Campana two different corers were used from a fixed rubber dinghy. The upper $20 \mathrm{~cm}$ of unconsolidated, water saturated sediment were recovered using an UWITEC Corer (http:// www.uwitec.at/). Every $2 \mathrm{~cm}$ subsamples of sediment were taken in the field. Subsequently, a core of $82 \mathrm{~cm}$ was taken with a Livingstone piston corer from 15 to $97 \mathrm{~cm}$ depth of sediment. This sediment section was recovered in an aluminum tube and stored under dark and cold $\left(4^{\circ} \mathrm{C}\right)$ conditions until processing.

Subsamples for pollen analysis were taken at $2 \mathrm{~cm}$ intervals except for a $1 \mathrm{~cm}$ sampling interval in the transition zone between the two different core sections $(14-19 \mathrm{~cm})$. In total 52 subsamples were processed applying standard pollen analytical methods (Fægri and Iversen 1989). Exotic Lycopodium spores were added as a marker to each subsample for calculation of concentrations. The pollen sum of a minimum of 300 pollen grains includes pollen of trees, shrubs and herbs as well as unknown and indeterminate pollen types. Based on this sum percentage data of each pollen type were calculated. Spores and algae (e.g. Botryococcus braunii) were also counted and quantified as percentages of the pollen sum. Charcoal particles $(5-150 \mu \mathrm{m})$ were counted on each pollen slide and presented as percentage data relative to the pollen sum. Additional concentration data were calculated for Botryococcus braunii, the pollen sum and charcoal particles.

Pollen and spore identification was mainly based on the reference collection kept at the University of Göttingen, which contains $\sim 3,000$ Neotropical (Behling 1993) and approximately 300 Ecuadorian pollen and spore types, and a published pollen reference from Colombia (Hooghiemstra 1984). Identified pollen types were classified in ecological groups referring to described potential natural vegetation types of the area by Homeier et al. (2008) and available data on plant ecology and distribution (Bussmann 2001; Lozano 2002; Marchant et al. 2002; Richter and Moreira-Muñoz 2005; Homeier and Werner 2008). Indicators of cultivation and plantation as well as unknown pollen types were grouped separately.

For pollen data calculation and illustration the software TILIA and TILIAGRAPH (Grimm 1991, 2004) was used. Classification of zones was based on a constrained clusters analysis of all pollen taxa performed by CONISS (Grimm 1987) and on changing abundances of the most important pollen taxa. A further subdivision of one zone was supported by significant variations in XRF data.

Non-destructive XRF-scanning was done using an ITRAX core scanner (Croudace et al. 2005; St-Onge et al. 2007) with a $1 \mathrm{~mm}$ step size. Element count rates are given in element peak areas (pa, element integral). The X-ray radiography was obtained with the same device. Subsequently, a principle component analysis (PCA) was done using $\log$ transformed values of all elements showing a mean of more than 100 pa (Fig. 2). Values of PC1 were multiplied by -1 in order to facilitate the comparison with the curves contributing to this PC.

PC1 reduces all the allochthonous minerogenic input parameters hitherto frequently used in other studies, such as the conservative lithogenic metal Ti (Shotyk et al. 2001; Haberzettl et al. 2005, 2006, 2007, 2008; Niemann et al. 2009) or Rb (Guyard et al. 2007), to one proxy. Hence, increases in that proxy represent an increase in runoff or eolian supply. Alternatively, PC1 mirrors the plant coverage in the catchment area. Low coverage especially immediately after a landslide would result in intensified erosion and therefore increased minerogenic input to the lake.

The incoherent/coherent (inc/coh) ratio may be used as an estimate of sediment organic content (Guyard et al. 2007; Rolland et al. 2008). This explains the opposite pattern of this ratio to $\mathrm{PC} 1$. If the minerogenic content decreases the relative proportion of organic material rises and vice versa.

Due to its stability and high resistance to chemical weathering, $\mathrm{Ti}$ is widely used in geochemical studies as a conservative metal, against which relative enrichments and depletions of more mobile major and trace elements like $\mathrm{Fe}$, $\mathrm{Pb}$ or $\mathrm{Cu}$ may be compared (Shotyk et al. 2001). The Fe/Ti ratio is a measure of redox processes. If the ratio is constant the $\mathrm{Fe}$ content resembles the minerogenic input and an influence of redox processes on this element is rather unlikely. For iron the critical $\mathrm{Eh}$ for reduction of $\mathrm{Fe}^{3+}$ compounds to more soluble $\mathrm{Fe}^{2+}$ compounds is $100 \mathrm{mV}$ ( $\mathrm{Sigg}$ and Stumm 1996). Therefore, if the redox potential drops to 
values below $100 \mathrm{mV}, \mathrm{Fe} / \mathrm{Ti}$ ratios will decrease. If the migrating $\mathrm{Fe}$ ions oxidize again they will stop migrating and increase the Fe/Ti ratio.

$\mathrm{Pb}$ is a measure of the lead content of the sediment relative to sediments deposited above or below. In contrast, the $\mathrm{Pb} / \mathrm{Ti}$ and $\mathrm{Cu} / \mathrm{Ti}$ ratio reflect the $\mathrm{Pb}$ and $\mathrm{Cu}$ input relative to the minerogenic input. This means that if the ratios are not constant the changes are either caused by variations in atmospheric deposition independent of eolian and fluvial input, or by displacement of ions within the profile.

For AMS radiocarbon dating three subsamples, one bulk sample from the bottom of the record and two small leaves further up in the core, were submitted to the University of Erlangen-Nürnberg, Germany and to the Poznan Radiocarbon Laboratory, Poland (Table 1). For calibration of the ${ }^{14} \mathrm{C}$ dates the online program CALIB 5.0.2 (Stuiver and Reimer 1993) with the Southern Hemisphere calibration set shcal04 (McCormac et al. 2004) was used. The calibrated dates given reflect the median ages of the $2 \sigma$ distribution, as a single robust estimate, such as the weighted average or median, should be used (Telford et al. 2004).

\section{Results}

\section{Lithology}

Macroscopic inspections revealed that the sediment mainly consists of homogenous black organic rich material. The lower part between 97 and $80 \mathrm{~cm}$ showed the highest sediment density. The water content increases gradually to the top of the core and the upper $15 \mathrm{~cm}$ of the sediment are explicitly unconsolidated and water saturated. This trend is confirmed by the X-ray image (Fig. 3). At the bottom of the record the $\mathrm{X}$-ray image reveals two zones (around 95 and $83 \mathrm{~cm}$ depth) of disturbed sediment separated by the most dense part of the record (93-87 cm depth). In the middle part of the core material of low density is found (Fig. 3). Unfortunately, no $\mathrm{X}$-ray information is available from the upper $15 \mathrm{~cm}$ as they had already been subsampled in the field.

Chronology and age-depth modelling

Radiocarbon dates show an age of A.D. $1880^{+75} /{ }_{-180}$ at $62 \mathrm{~cm}$ depth of sediment and a basal age of the sediment core at $97 \mathrm{~cm}$ of A.D. $1470^{+150} /_{-45}$ (Table 1). A further radiocarbon date at $73 \mathrm{~cm}$ depth of sediment indicates an age of A.D. $1450^{+165 /}{ }_{-45}$, which is in the same range as the basal date. Both ages, at 73 and $97 \mathrm{~cm}$, show a distinct offset to the upper age in the record.

As the formation of the lake is supposed to be associated with a landslide, which probably caused bare surfaces in the catchment area to be prone to erosion, an increased sedimentation rate as well as intense reworking seems to be plausible after soil movement. This might also have led to the inclusion of reworked organic compounds in the dating for the lowermost ages. The potential reworking is supported by $\mathrm{PC} 1$, which after a pronounced decrease from the bottom of the record up to $75 \mathrm{~cm}$ shows a final small increase from 75 to $72 \mathrm{~cm}$. As PC1 represents allochthonous minerogenic input it is also possible that allochthonous organic components might have been transported to the lake. Hence, these two dates yield only a terminus post quem of $\sim$ A.D. 1470 for the base of the record and were excluded from the age-depth model (Fig. 4). Therefore, only one radiocarbon age can be used and other time markers have to be included generating an appropriate agedepth model for the record above the uppermost rejected date, i.e. $72 \mathrm{~cm}$. The occurrence of Pinus pollen can be used as time marker, as this European tree species was introduced to Ecuador around the turn of the twentieth century (Neill 1999). Therefore, an extra scan of pollen slides exclusively for Pinus pollen starting at the bottom of the record was done in addition to the pollen count. The first Pinus pollen was observed at $55 \mathrm{~cm}$ (not included in the pollen sum and thus not displayed in the pollen diagram), which consequently indicates an age of A.D. 1900 for this sediment depth.

The age-depth model for the upper part of the record was built using the sediment/water interface as a time marker for the year of coring, i.e. 2007, the first occurrence of Pinus and the one accepted radiocarbon age at $62 \mathrm{~cm}$. Linear interpolation between the sediment/water interface and the uppermost radiocarbon date does not account for the fact that potentially the top of the uppermost part of the record might be less affected by compaction. Hence, a second order polynomial function $\left(y=-0.00129 x^{2}+\right.$ $4.53182 x-3893.18714$ ) was chosen (Fig. 4). The mean sedimentation rate for the upper part of the core is $4.97 \mathrm{~mm}$ $\mathrm{a}^{-1}$ or $\sim 2 \mathrm{a} \mathrm{cm}^{-1}$.

Table 1 List of radiocarbon dates and calibrated ages from Laguna Campana

\begin{tabular}{llllll}
\hline Lab. code & Depth $(\mathrm{cm})$ & $\begin{array}{l}\text { Sample } \\
\text { description }\end{array}$ & ${ }^{14}$ C Age (B.P.) & $\begin{array}{l}\text { Calibrated (A.D.) } \\
(\text { median })\end{array}$ \\
\hline Poz-24273 & 62 & Leaf & $101 \pm 27$ & 1880 & $1700-1955$ \\
Erl-13235 & 73 & Leaf & $490 \pm 43$ & 1450 & $1405-1615$ \\
Erl-11389 & 97 & Bulk & $456 \pm 36$ & 1470 & $1425-1620$ \\
\hline
\end{tabular}




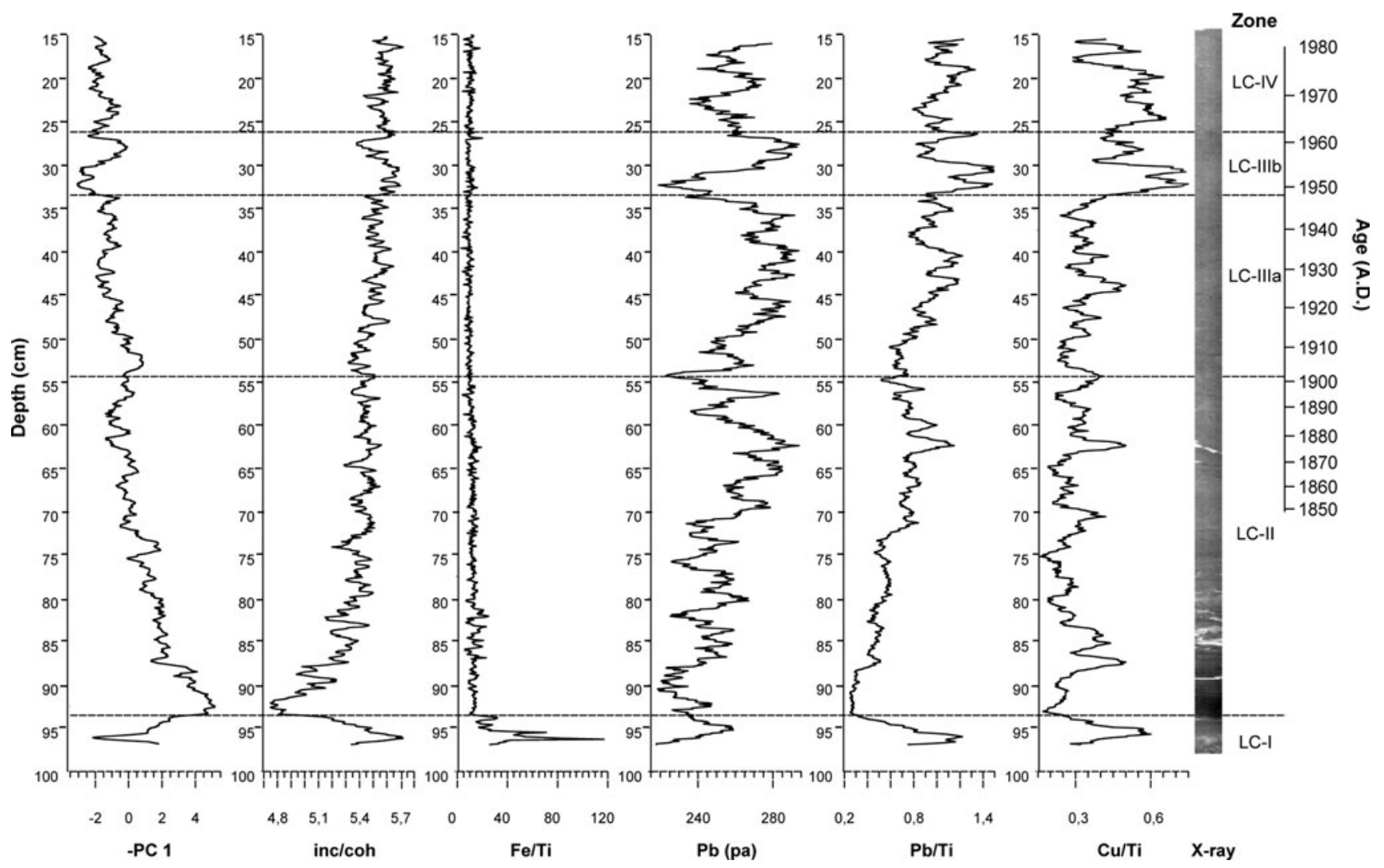

Fig. 3 Profiles of Principle Component 1 (PC1), XRF-scanning elemental analyses and radiograph of the sediment record from Laguna Campana. Values of PC1 were multiplied by -1 in order to facilitate the comparison with the curves contributing to this PC.

\section{XRF and pollen data}

The PCA of the XRF data shows that PC1 is mainly formed by $\mathrm{K}, \mathrm{Ti}, \mathrm{Fe}, \mathrm{Rb}, \mathrm{Zr}$ and $\mathrm{Cu}$ (Fig. 2). Hence, $\mathrm{PC} 1$ is used as a reduction of these elements to one single parameter. In contrast $\mathrm{Pb}$ contributes about $88 \%$ to $\mathrm{PC} 2$. $\mathrm{PC} 1$ and 2 together account for $63.3 \%$ of the variations. The absence of a correlation between $\mathrm{Ti}$ as one of the major contributors to $\mathrm{PC} 1$ and $\mathrm{Pb}$ is not only shown by the PCA itself but also by the correlation coefficient of these two elements $\left(R^{2}=0.01\right)$. A low correlation coefficient was also found for $\mathrm{Cu}$ and $\mathrm{Ti}\left(R^{2}=0.11\right)$.

Out of 156 pollen and 48 spore types distinguished, the 35 most significant taxa are shown in a percentage diagram. Also presented are percentages of bryophytes, including Sphagnum and Phaeoceros, and the algae Botryococcus braunii (Fig. 5). Additionally, a summary percentage diagram illustrates 11 different groups of taxa, charcoal data as well as concentrations of pollen and Botryococcus braunii (Fig. 6).

Constrained cluster analysis as well as pollen and XRF data observation resulted in four main zones (LC-I to IV) and one subdivision of the third zone (LC-III a, LC-III b).
XRF-data are plotted as ratios and $\mathrm{Pb}$ as element peak area (pa). Data for $\mathrm{PC} 1$ are smoothed with a 3-point moving average, for $\mathrm{Pb}$ with a 21-point moving average and for $\mathrm{Pb} / \mathrm{Ti}$ as well as $\mathrm{Cu} / \mathrm{Ti}$ with an 11-point moving average

These zones reflect major environmental changes in the lake and the study area. Displayed pollen taxa with $<2 \%$ representation are generally not discussed in the text.

Zone LC-I (97-92 cm, 3 pollen samples, base of the record)

Values for PC1 are low in LC-I, being lower only in the most recent sediments of LC-IIIb and LC-IV (Fig. 3). However, there is a distinct rise to the top of this zone peaking at the very bottom of the next zone LC-II. The opposite can be observed for all other parameters: after a clear maximum in LC-I (representing the highest values of the whole record for the inc/coh and $\mathrm{Fe} / \mathrm{Ti}$ ratios) there is a rapid decline towards LC-II where values bottom out in the lowermost part. In general there is an opposite pattern of $\mathrm{PC} 1$ vs. inc/coh which can be observed in the whole record.

The zone LC-I is dominated by very high proportions of páramo taxa decreasing to the top of the zone from 83 to $45 \%$. This is mainly caused by a decrease in Poaceae pollen from 80 to $32 \%$. Cyperaceae pollen contributes to the páramo group with values between 2 and $15 \%$. The low represented subpáramo taxa $(7-11 \%)$ become more 


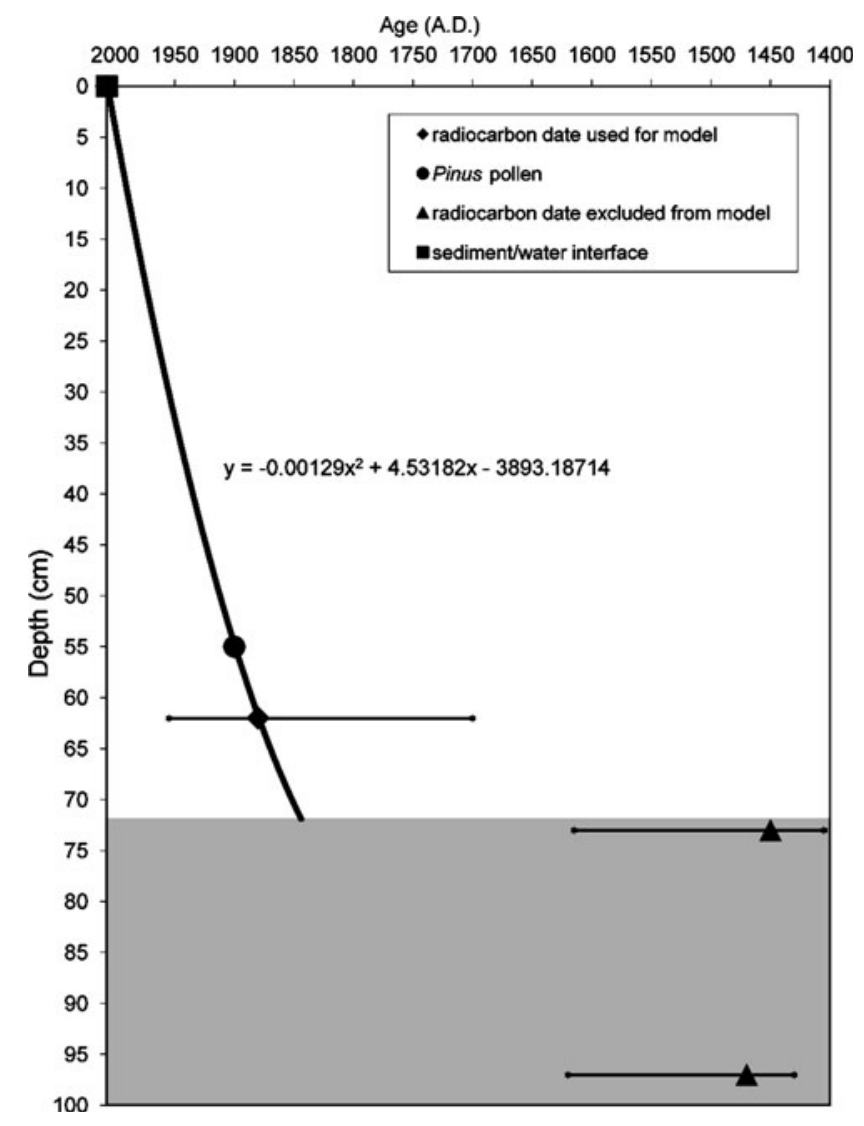

Fig. 4 Age-depth model for the Laguna Campana lake sediment record. The shaded area represents a section potentially yielding ages that are too old, possibly related to the initial landslide forming the lake and subsequent bare soil areas in the catchment

abundant to the top of the zone as shown for instance by pollen of Melastomataceae (0-6\%) and Asteraceae subf. Asteroideae (5-9\%). UMF taxa first show low pollen percentages of $7 \%$ but increase markedly within this zone to $32 \%$. This is mainly due to an initial increase of Alnus pollen from 5 to $24 \%$. Subsequently, Weinmannia pollen appears up to $3 \%$. Pollen of Hedyosmum (1-2\%) and Myrica (0-3\%) represents other important UMF taxa. LMF taxa show low values (0-3\%) mainly of Moraceae/Urticaceae pollen (0-2\%). One pollen grain of Zea mays $(0.3 \%)$ is present in this zone. Pteridophyta spores increase to the top of the zone from 15 to $27 \%$, to which Cyatheaceae and Lycopodiaceae spores contribute up to $2 \%$ each. Colonies of the green algae Botryococcus braunii are absent in the bottom sample but increase to the top of the zone up to $3 \%$, reaching a concentration of 8495 colonies $\mathrm{cm}^{-3}$. Charcoal particles $(1,290-3,230 \%$ relative to the pollen sum) show highest percentages and concentrations (2.3-5.3 million particles $\mathrm{cm}^{-3}$ ) in this zone. Pollen concentration increases to the top of the zone from 160,000 grains $\mathrm{cm}^{-3}$ to the highest concentration of 326,000 grains $\mathrm{cm}^{-3}$.
Zone LC-II (92-54 cm, 19 pollen samples, base of the record to A.D. 1900)

The highest values for $\mathrm{PC} 1$ are followed by a progressive decline towards the top of this zone (Fig. 3). Again, the opposite can be observed for the inc/coh ratio: starting with lowest values of the record it rises continuously. The same applies to $\mathrm{Pb}$ and the $\mathrm{Pb} / \mathrm{Ti}$ ratio respectively. From the bottom of LC-II upwards the Fe/Ti ratio shows only minor variations up to the top of the record. The $\mathrm{Cu} / \mathrm{Ti}$ ratio presents some kind of cyclical pattern but exhibits no trend (Fig. 3).

Decreased páramo proportions (23-39\%) stabilize in this zone, indicated mainly by lower pollen frequencies of Poaceae (19-27\%) and Cyperaceae (3-8\%). Subpáramo taxa remain stable (4-10\%), primarily due to pollen percentages of Melastomataceae (3-9\%), Asteraceae subf. Asteroideae (2-10\%) and Ericaceae (0-3\%). UMF taxa are well represented, but decrease in the upper part of the zone from 46 to $33 \%$. This is mainly caused by a marked increase of Weinmannia pollen from 7 to $29 \%$ at the beginning of this zone and a subsequent decrease to $19 \%$ in the upper part of the zone. Alnus pollen shows a decreasing trend from $24 \%$ to a minimum of $8 \%$. Pollen percentages of Hedyosmum (0-4\%), Myrica (1-4\%) and Myrsine (1-3\%) are stable but lower. LMF taxa are still poorly represented but reach the highest proportion of $13 \%$, mainly through increasing values of Moraceae/Urticaceae pollen from 2 to $7 \%$ as well as higher pollen percentages of Alchornea (0-3\%) and Acalypha (0-2\%). Pteridophyta spores increase slightly to the top of the zone from 15 to $17 \%$, mainly through increasing unknown types (not shown in the diagram). The most frequent known spore types such as Cyatheaceae, Lycopodiaceae and Huperzia (0-2\%) remain stable. Sphagnum spores appear and increase to the end of this zone up to 5\%. After a distinct increase in the first half of the zone Botryococcus braunii colonies show the highest proportion of $2,452 \%$ at a depth of $81 \mathrm{~cm}$ and decrease subsequently to $294 \%$. This is mirrored by the concentration data of Botryococcus braunii starting at 20,000 colonies $\mathrm{cm}^{-3}$ at the base of this zone, peaking at 5.5 million colonies $\mathrm{cm}^{-3}$ at $81 \mathrm{~cm}$ depth and decreasing subsequently to 400,000 colonies $\mathrm{cm}^{-3}$. Varying charcoal percentages (802-2242\%) and concentrations (1.0-4.2 million particles $\mathrm{cm}^{-3}$ ) show a decreasing trend but the last sample in this zone yields a high value of 2.6 million particles $\mathrm{cm}^{-3}$ which is twice as much as the previous sample. Pollen concentrations decrease slightly to the top of this interval from 283,000 grains $\mathrm{cm}^{-3}$ to 87,000 grains $\mathrm{cm}^{-3}$ parallel to charcoal concentrations. The highest pollen concentration occurs at the same depth as the concentration of Botryococcus braunii colonies peaks. 


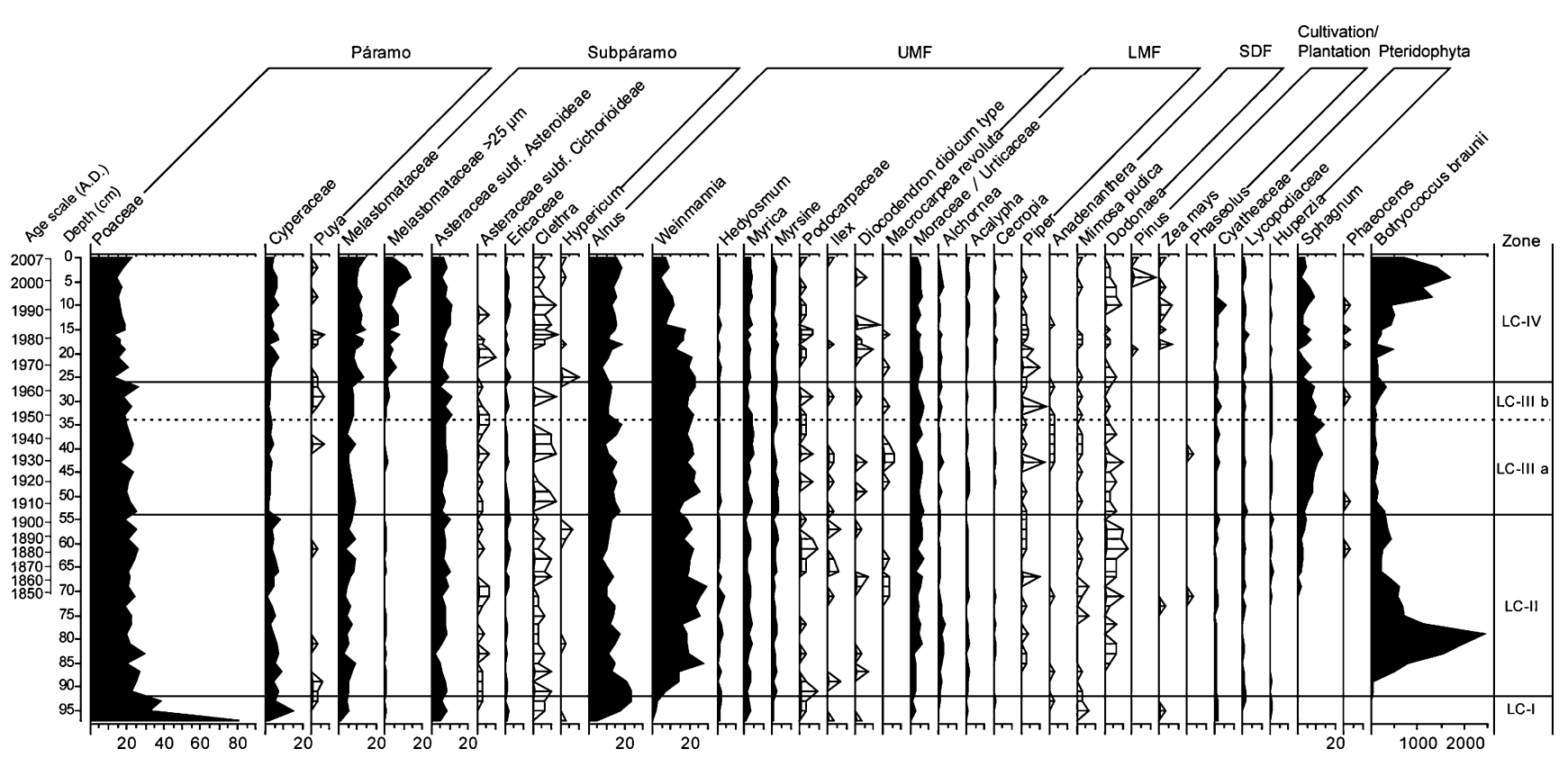

Fig. 5 Pollen percentage diagram of Laguna Campana illustrating the most important and frequent taxa grouped into potential natural vegetation types of páramo, subpáramo, upper mountain rainforest (UMF), lower mountain rainforest (LMF) and semideciduous

Zone LC-IIIa $(54-34 \mathrm{~cm}, 10$ pollen samples, A.D. 1900-1950)

The trends in element composition described for LC-II continue in LC-IIIa. However, magnitudes are much lower.

Páramo taxa show lower values between 29 and $20 \%$ than in zone LC-II, which is primarily due to lower proportions (2-5\%) of Cyperaceae pollen. Compared to the top of the previous zone UMF taxa are represented by slightly higher proportions between 38 and $49 \%$, mainly because of higher pollen percentages of Weinmannia (14-26\%) and Alnus (10-18\%). A first pollen grain of Phaseolus is found in this zone. Sphagnum spores markedly increase to the highest percentage of $14 \%$ at the top of the zone, while colonies of Botryococcus braunii continue to decrease markedly reaching very low percentages of $60 \%$ and concentrations of 74,000 colonies $\mathrm{cm}^{-3}$. Charcoal particles $(783-1,581 \%)$ are less frequent than in the previous zone and show stable but low concentrations with a maximum of 1.4 million particles $\mathrm{cm}^{-3}$. The slightly decreasing trend in pollen concentration as observed in the previous zone continues, reaching minimum values of 83,000 grains $\mathrm{cm}^{-3}$.

Zone LC-IIIb (34-26 cm, 4 pollen samples, A.D. 1950-1960)

Apart from those in LC-I, variations in all parameters related to element composition are highest in LC-IIIb. The interandean forest (SDF) together with cultivation and plantation indicators. Taxa with $<2 \%$ representation are shown by percentage bars with an exaggeration factor of $10 \times$

lowest values in $\mathrm{PC} 1$ and $\mathrm{Pb}$ are followed by values in the range of the upper part of LC-IIIa. In contrast the highest values of the record in the inc/coh, $\mathrm{Pb} / \mathrm{Ti}$ and $\mathrm{Cu} / \mathrm{Ti}$ ratios are followed by much lower values.

In this subzone pollen data are comparable to the previous zone (LC-IIIa). However, UMF taxa decrease from 41 to $36 \%$, most notably due to lower values of Alnus (11-12\%) and Myrica (1-4\%) pollen. Sphagnum spores show slightly lower values between 7 and $10 \%$ than at the top of the previous subzone. Botryococcus braunii colonies show an opposite trend of slightly increasing values to the top of LC-IIIb reaching values of $314 \%$ and concentrations of 260,000 colonies $\mathrm{cm}^{-3}$.

Zone LC-IV (26-0 cm, 16 pollen samples, A.D. 1960-present)

LC-IV shows only small variations in PC1 and the inc/coh ratio. $\mathrm{Pb}, \mathrm{Pb} / \mathrm{Ti}$ and $\mathrm{Cu} / \mathrm{Ti}$ show some changes at high levels.

In this interval greater changes in the pollen composition are observed than in zones LC-IIIa/b. Páramo taxa remain stable between 15 and 27\%, but Cyperaceae pollen shows higher proportions (2-7\%). Subpáramo taxa increase towards the top reaching highest values of $24 \%$. This is mainly due to higher pollen percentages of Melastomataceae $(8-15 \%)$ exceeding those of all prior zones. In particular the pollen type of Melastomataceae $>25 \mu \mathrm{m}$ appears for the first time with considerably high percentages and increases 


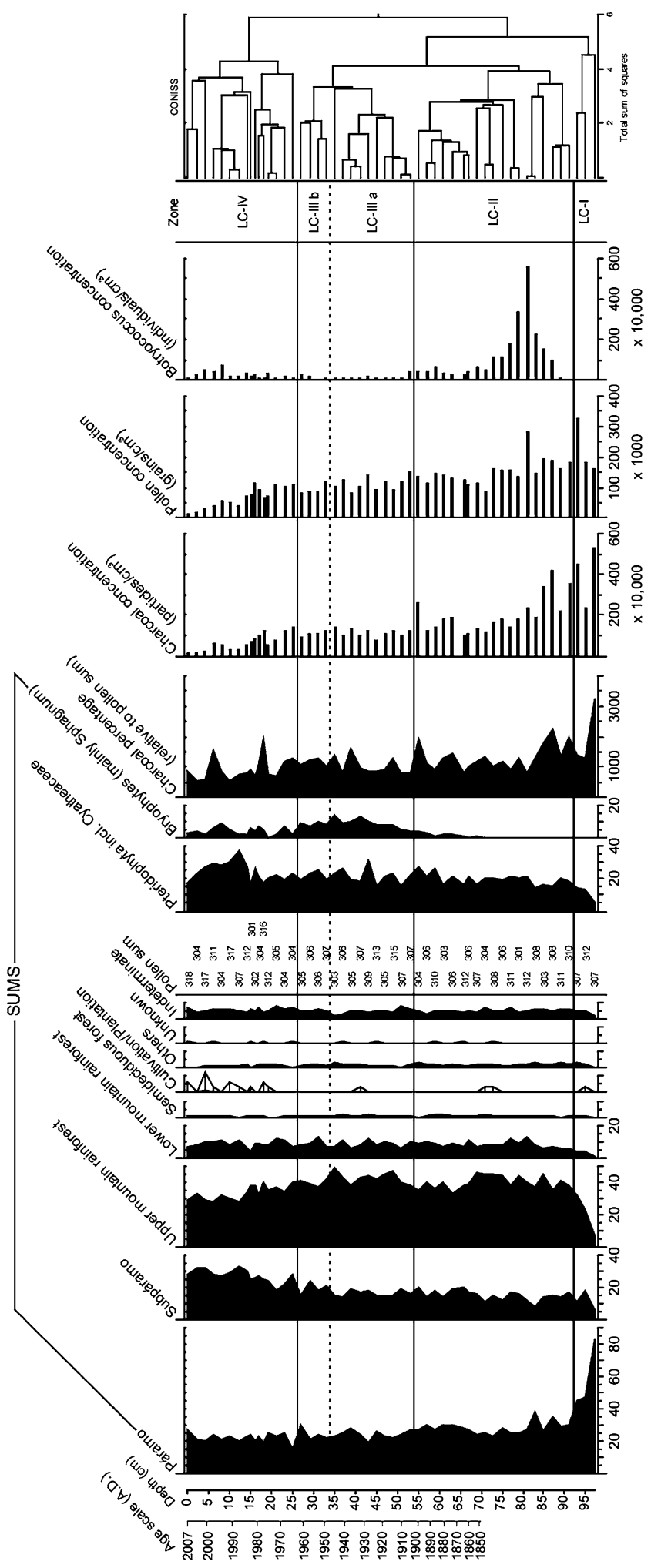

Fig. 6 Summary pollen diagram showing vegetation groups, concentration data for pollen, charcoal and Botryococcus together with CONISS cluster analysis of the Laguna Campana sediment record markedly to reach a highest proportion of $14 \%$ at the top of this zone. A distinct decrease of UMF taxa towards the top from 40 to $28 \%$ is primarily due to the marked decline of Weinmannia pollen from 23 to $4 \%$. In contrast Alnus pollen increases slightly from $8 \%$ to $18 \%$. LMF taxa (4-11\%) and its components such as Moraceae/Urticaceae pollen (3-6\%) are stable above zone LC-II. Pinus (0-1\%) and Zea mays $(0-1 \%)$ pollen is more frequent. Pteridophyta spores, mainly unknown types, show higher proportions in the second half of this zone than in all previous zones and reach maximum values of $38 \%$. Spores of Cyatheaceae (0-7\%) and Lycopodiaceae (0-3\%) do not show notable changes. Sphagnum spores (0-9\%) fluctuate inversely to Botryococcus braunii colonies. However, Sphagnum is less important in this zone than in the previous one, while Botryococcus braunii colony percentages increase markedly from 85 to $1,696 \%$ to the top. However only slightly higher Botryococcus braunii concentrations of a maximum of 520,000 colonies $\mathrm{cm}^{-3}$ are observed compared to the previous zone. Charcoal particles show high variable percentages $(543-1,914 \%)$ but concentrations clearly decrease to the top of the zone to the minimum of 108,000 particles $\mathrm{cm}^{-3}$. The same decreasing trend is observed for pollen concentrations reaching their minimum of 13,000 grains $\mathrm{cm}^{-3}$ in the uppermost sample.

\section{Interpretation and discussion}

Lake genesis and subsequent vegetation development

Geomorphologic observations suggest that the lake was formed by a shallow landslide forming a dam towards the downhill side of the lake. Due to the high relief energy, with steep slopes resulting in geomorphologic instability, shallow landslides are common in the tropical mountain forest area of the Ecuadorian Andes (Schrumpf et al. 2001; Bussmann et al. 2008; Gradstein et al. 2008). Many gaps without vegetation or with early succession stages of vegetation also indicate erosion and mass movements surrounding the study area (Wilcke et al. 2003).

The fact that it was impossible to penetrate any further into the sediment suggests that the whole sedimentary sequence of Laguna Campana was recovered. A clear separation of a zone of low minerogenic input together with high organics instead of a more mixed signal might indicate that only the uppermost part of the soil horizons were displaced, which become rich in humus towards higher elevations (Gradstein et al. 2008). Removal of the 
organic layer and the uppermost part of the A-horizons in the head area and redeposition of the material in the foot area is typical of the shallow landslides described in the study area (Bussmann et al. 2008). The highest charcoal percentages and concentrations found in the bottom sample indicate that fires may have played a significant role in soil erosion and furthermore may have triggered the landslide causing lake formation.

$\mathrm{Fe} / \mathrm{Ti}$ ratios are much lower in the upper part of the record. Therefore, Fe migration within the sediment column appears to be rather unlikely. Hence, we speculate that the iron enrichment in LC-I is a relict of former soil formation processes. Most studies dealing with vertical distribution of metals in soil profiles report a tendency toward concentration in the upper horizons. The surface enrichment of metals in soils may be a result of chemical complexing by organic compounds (Mirsal 2008). Low pH might have caused an upward migration of $\mathrm{Fe}$ as acidic and reducing conditions are the most favourable for metal solubilisation (Chuan et al. 1996; Charlatchka and Cambier 2000). Reductive dissolution of clay-sized Fe(III) hydroxides and vertical and lateral leaching of the released $\mathrm{Fe}$ was also suggested in an altitudinal transect close to the study area (Wilcke et al. 2008). The same mechanisms might influence $\mathrm{Pb} / \mathrm{Ti}$ and $\mathrm{Cu} / \mathrm{Ti}$ ratios. For example for $\mathrm{Cu}$ fixation mainly organic substances as well as pedogenic Feand Mn-oxides are important, as are pedogenic oxides, notably for $\mathrm{Pb}$ enrichment (Hiller and Brümmer 1991; Chuan et al. 1996; Charlatchka and Cambier 2000). As most heavy minerals form complexes with humic acids they are preferentially enriched in the top humus layer or topsoil (Brümmer et al. 1986). Additionally, an enrichment of $\mathrm{Pb}$ and $\mathrm{Cu}$ in topsoil might be caused by fallout from atmospheric sources before the landslide. Unfortunately, no soil investigations have been carried out in our study to verify this hypothesis of $\mathrm{Fe}, \mathrm{Pb}$ and $\mathrm{Cu}$ enrichment in topsoil. Although soil development might vary considerably between the warm and humid eastern side of the Cordillera Real (Beck et al. 2008b), investigations on the western part showed reddish subsurface horizons indicating redoximorphic processes (Beck et al. 2008b) or an enrichment of $\mathrm{Fe}$ at least in the A-horizon (Schrumpf et al. 2001). Therefore, if this scenario is valid for the study site it provides a hint that the bottom of the record is formed by the upper part of a displaced soil and that the whole sediment sequence was recovered. If there had been a number of slumps rather than just one, the data suggests that at least the last event was recovered completely.

According to the two lowermost radiocarbon dates which probably represent the formation of Laguna Campana the respective landslide has a terminus post quem of $\sim$ A.D. 1470. This indicates that landslides already occurred during this time. As the landslide removed the vegetation cover from a large part of the catchment of Laguna Campana, this probably led to further erosion which is mirrored by minerogenic input. Increased post-landslide erosion on sparsely vegetated landslide areas was also previously observed by Bussmann et al. (2008). After vegetation recovery erosion and hence minerogenic input decreases in LC-II (Fig. 3).

Further evidence for a complete recovery of the sediment sequence deposited in Laguna Campana comes from pollen analysis representing mainly local vegetation changes. The bottom sample showed very high percentages (up to $80 \%$ ) of Poaceae, indicating that the vegetation at the disturbed area most likely consisted of high Poaceae proportions before the landslide occurred. As the surroundings after the landslide probably still held vegetation rich in grasses, these could quickly become established in the area. It seems that during this first successional stage other vegetation components were initially suppressed by the dense grass layer. This is supported by studies of Bussmann et al. (2008), showing that on landslides grasses build a dense layer and limit the establishment of bush species. The high Poaceae presence of $\sim 20 \%$ persisting after the initial peak represents a remaining above-average grass proportion in the study area, as such high grass abundances normally occur in much higher elevations where páramo is found (Weng et al. 2004a).

After this first establishment of grasses, vegetation succession began, even though a high proportion of grass remained. Cyperaceae grew up in wet locations such as small ground depressions and watersides. At the same time pioneer trees of Alnus, here Alnus acuminata, expanded on moist and probably disturbed sites (Weng et al. 2004b) and their pollen reached its highest proportion of $24 \%$ in an early successional stage. Some Alnus pollen could have originated at lower elevations and might have been dispersed to higher altitudes, but as pollen proportions never fell below 5\% it probably reflects local occurrence (Weng et al. 2004a). Ongoing vegetation regeneration led to an expansion of Weinmannia up to $\sim 30 \%$ in the beginning of zone LC-II, while Alnus declined over the same interval. As different species of Weinmannia have a large altitudinal range in the study region of the Podocarpus National Park (Lozano et al. 2003; Homeier and Werner 2008), Weinmannia pollen could have been transported by wind. However, most species occur in the UMF and subpáramo zone (Niemann et al. 2009) and studies carried out in New Zealand (Moar 1970) revealed that high pollen frequencies of Weinmannia certainly imply local dominance. Based on that, the high pollen presentation of Weinmannia probably indicates that this genus contributing to the upper mountain rainforest recovered in the area to a certain extent, possibly due to decreasing human disturbances. Mainly Hedyosmum, Myrica and Myrsine were associated with dominating trees of 
Weinmannia. Together with Melastomataceae and Asteraceae this vegetation composition constituted a considerable part of the local vegetation. Woody plants probably represented small trees and shrubs in the understory. Myrica and Myrsine also are pioneer species, indicative of disturbance.

A high occurrence of pteridophyta was established rapidly during the successional stages of Alnus and Weinmannia and increased throughout the whole record from 6 up to $38 \%$. This gives an indication of vegetation structure, as ferns may be characteristic of a wet understory but also show high occurrences on open soils after disturbance (Bussmann et al. 2008). Hence, pteridophyta at Laguna Campana indicate most likely sparse vegetation on open soils or subsequently open secondary forests stands. This converted vegetation composition probably harbors much less biodiversity than undisturbed natural UMF occurring elsewhere.

Anthropogenic impact and further vegetation changes

A crucial factor for the vegetation development at Laguna Campana is human influence. Already the bottom sample showed the highest charcoal percentage of 3,230\% relative to the pollen sum and the highest charcoal concentration of 5.3 million particles $\mathrm{cm}^{-3}$, indicating high fire frequency. Former studies in the Podocarpus National Park region concluded that increasing fire frequencies during Holocene times were most likely of anthropogenic origin. Common fires during late Holocene times concurrent with high grass pollen occurrence have been previously interpreted as indication of early human activities (Niemann and Behling 2008a; Niemann et al. 2009).

Given the fact that fires were used for slash and burn purposes (Niemann and Behling 2008a) a natural cause for fire is probably negligible. During the whole duration of the record fires occurred and affected the vegetation. These might have been more intense in this area, compared to more easterly located sites in the PNP, due to drier climatic conditions. The lower charcoal concentration in the uppermost zone (LC-IV) probably does not reflect decreasing fire frequency. Charcoal percentages similar to those in previous zones suggest rather constant fire occurrences. The high water content and lower sediment compaction in the top samples may be responsible for the lower concentration data calculated per sampled volume. This applies to charcoal as well as pollen concentrations. The initial high proportions of Poaceae after the landslide may also indicate human impact. As Bussmann et al. (2008) described, a first succession of a dense grass layer occurs particularly on anthropogenically caused landslides and differs from that on natural ones. Human land use had already opened up the vegetation cover before the landslide event and probably reduced the local biodiversity. This could have favored Poaceae distribution at elevations up to $2,500 \mathrm{~m}$ a.s.1., where naturally UMF dominates.

A marked decrease of Weinmannia during very recent times also indicates human activities. High fire frequencies strongly reduce the occurrence of Weinmannia (Niemann and Behling 2009). As burning for forest clearance or new farming areas is still a common method used by settlers and has been so for centuries (Beck et al. 2008c), Weinmannia may have been seriously affected by these fires during the last decades. This supports the assumption that fires remained frequent in the zone LC-IV. Additionally, Weinmannia might have been the target of timber extraction. Concurrently with the decline in Weinmannia during most recent times, Melastomataceae has increased markedly. While the pollen type including all Melastomataceae $<25 \mu \mathrm{m}$ only expanded slightly (8-15\%) in the uppermost zone, the pollen type $>25 \mu \mathrm{m}$ occurred for the first time in high abundances. The high pollen input from Melastomataceae $>25 \mu \mathrm{m}$ probably originated from a local stand of Melastomataceae at the shore of Laguna Campana observed during field work.

Furthermore, the crop plant Zea mays and the domesticated wild bean Phaseolus, already present in zone LC-I, evidence permanent land use in the area. Ancient human settlements have taken place in the area since $\sim 4000$ years cal B.P. (Guffroy 2004). The Inca occupied the area of Loja and Zamora in the middle of the fifteenth century. During their 70-year rule in southern Ecuador (A.D. 1463-1531) the indigenous group of the Saraguros was brought to the Ecuadorian highlands. Their traditional mixed cultivation system featured maize, beans, potatoes and other tubers. As early as the nineteenth century cattle breeding supplemented their livelihood (Pohle 2008).

However, lower abundances of cultivation indicators found throughout the zones LC-I to LC-III suggest a phase of less human activity compared with that in most recent times. This is supported by another nearby palynological study, in which the time period between the seventeenth and twentieth centuries was identified as a phase of lower human activity (Niemann and Behling 2008a). Thus in particular, the more frequent Zea mays pollen found in zone LC-IV suggests expanded cultivation during the last decades. This may be related to mestizo settlements in the study area founded during the acceleration of the Latin American Industrialization in the mid twentieth century (Niemann and Behling 2008a; Pohle 2008). Nowadays agriculture is still the most important economic activity in southern Ecuador. In the Loja province $44 \%$ of the economically active population works in agriculture (INEC 2001). Population pressure and improved infrastructure have opened even ecologically unsuitable areas to agricultural colonization during the past 50 years (Pohle 2008). The low amount of canopy trees like Clethra and Podocarpus found in the 
pollen diagram probably results from the fact that they were already objectives for wood extraction in the mid sixteenth century after the Spanish conquest (Guffroy 2004), mainly for the construction of the city of Loja.

Pinus pollen found in the record gives evidence of European influence in the study area. Pines were introduced only after colonization of the southern hemisphere by Europeans (Richardson 2000) at the beginning of the 20th century. Today large stands of introduced Pinus can be found in some areas of the Inter-Andean valleys (Neill 1999). Pinus pollen found more frequently in the uppermost zone LC-IV confirms the expansion of plantations during the last decades.

Although the present vegetation near Laguna Campana is composed of a considerable proportion of Puya, pollen of Puya is poorly represented in the pollen diagram because of its rare flowering. However, Puya pollen was found in samples from the lower zones as well as in the most recent samples. Apparently, Puya was already part of the vegetation around Laguna Campana in former times and persisted till today. Puya observed in the field seems to be fire resistant, which probably favored long term existence in this area.

A different kind of human impact seems to be reflected by heavy metals. The increase in $\mathrm{Pb} / \mathrm{Ti}$ ratio from the bottom to the top of the record indicates enrichment in $\mathrm{Pb}$ relative to Ti. As Ti, which is represented by $\mathrm{PC} 1$ in Fig. 3 decreases continuously, the increase in the ratio might also be caused by a constant supply of $\mathrm{Pb}$ which is independent of the supply of lithogenic input. However, absolute counts for $\mathrm{Pb}$ also show an increasing trend over the record. Chemical diagenesis seems to be of minor importance as above the peak in LC-I the Fe/Ti ratio varies only little. If $\mathrm{Pb}$ had migrated upwards in the profile, variations would have been observed in the $\mathrm{Fe} / \mathrm{Ti}$ ratio as $\mathrm{Pb}$ is less mobile than Fe (Charlatchka and Cambier 2000; Dorronsoro et al. 2002). There is also a growing body of information for ombotrophic peat bogs suggesting that $\mathrm{Pb}$ is immobile in this environment (Shotyk et al. 2005). The continuous rising trend of $\mathrm{Pb}$ from the bottom to the top of the record impedes the calculation of an enrichment factor because no natural background deposition of $\mathrm{Pb}$ was recovered in the record. As the XRF Scanner provides only semi-quantitative data, it is neither possible to obtain absolute inputs nor distinguish between lithogenic and anthropogenic components in the same way as has been done in previous work (Shotyk et al. 2001, 2005; Koinig et al. 2003). Nevertheless, the rise in $\mathrm{Pb}$ and $\mathrm{Pb} / \mathrm{Ti}$ respectively suggests an enrichment of $\mathrm{Pb}$ independent of lithogenic supply from the beginning of the record. Since chemical diagenesis does not seem to have been the driver we suggest an increased atmospheric supply in this case as the atmospheric loading is especially important for lead. It is estimated that over
95\% of the lead is of anthropogenic origin (Salomons and Förstner 1984). Similar observations have been made in lakes and peat profiles in Europe (e.g. Hettwer et al. 2003; Koinig et al. 2003; Shotyk et al. 2005; Guyard et al. 2007) and other South American countries like Peru or Bolivia (Abbott and Wolfe 2003; Cooke et al. 2007, 2008).

Distinct $\mathrm{Pb}$ anomalies were attributed to long range transport of atmospheric $\mathrm{Pb}$ contamination from $\mathrm{Pb}$ mining and smelting during Roman times in Europe (Hettwer et al. 2003; Shotyk et al. 2005; Guyard et al. 2007). The same studies show an even more distinct $\mathrm{Pb}$ peak related to the introduction of aerosols from leaded gasoline combustion or coal burning (Koinig et al. 2003; Shotyk et al. 2005). In Bolivia and Peru atmospherically derived input is also associated with smelting processes. Following the Inca conquest of the Andes A.D. 1450, marked increases in $\mathrm{Pb}$ are noted at all study sites and after the Hispanic conquest, large increases in $\mathrm{Pb}$ pollution are noted, only to be superseded by industrial development (Cooke et al. 2007, 2008). The source of the lead in the study area remains to be identified, but combustion can be assumed at least during subrecent times. Surprisingly, there is no contemporaneous rise in $\mathrm{Cu}$ from LC-I to LC-IIIa. Although there are variations, it remains in the same range. Only in LC-IIIb ( A.D. 1950) is there a distinct rise in $\mathrm{Cu} / \mathrm{Ti}$ which is contemporaneous with the highest values in $\mathrm{Pb} / \mathrm{Ti}$ but also the lowest values in $\mathrm{PC} 1$ and $\mathrm{Pb}$. This either indicates a further increase in the atmospheric supply of heavy metals or a greater dependence of the ratio signal on lithogenic input. Elevated $\mathrm{Cu}$ and $\mathrm{Pb}$ contamination was found close to small scale gold mining areas in southern Ecuador, such as in the Nambija region approximately $20 \mathrm{~km}$ east of the study site. The main gold rush started there during the 1980s but due to different extraction methods primarily waterways have been affected by the main contaminants which consist of $\mathrm{Cu}, \mathrm{Pb}$ and $\mathrm{Cd}$ (Swedish Environmental Systems 1999; Tarras-Wahlberg et al. 2000).

\section{Hydrological variations}

Minerogenic input (PC1) is probably related to lake level variations as higher precipitation causing higher lake levels will also cause an increase in erosion (Haberzettl et al. 2007). The green algae Botryococcus braunii is known to thrive in freshwater bogs, temporary pools, ponds and lakes (Batten and Grenfell 1996). In other studies Botryococcus has already been used as indicator of open water conjoined with other indications (Davis 1999; Niemann and Behling 2009). Higher Botryococcus presence is mostly coupled with increases in $\mathrm{PC} 1$ values in the record (Fig. 7). Accordingly, both are interpreted as occurring concurrently with increased moisture availability. In some cases increased PC1 values are observed without an increase in 
Fig. 7 Comparison of Principle Component 1 (-PC1, 3-point moving average) representing minerogenic input and Botryococcus colonies related to the total pollen sum

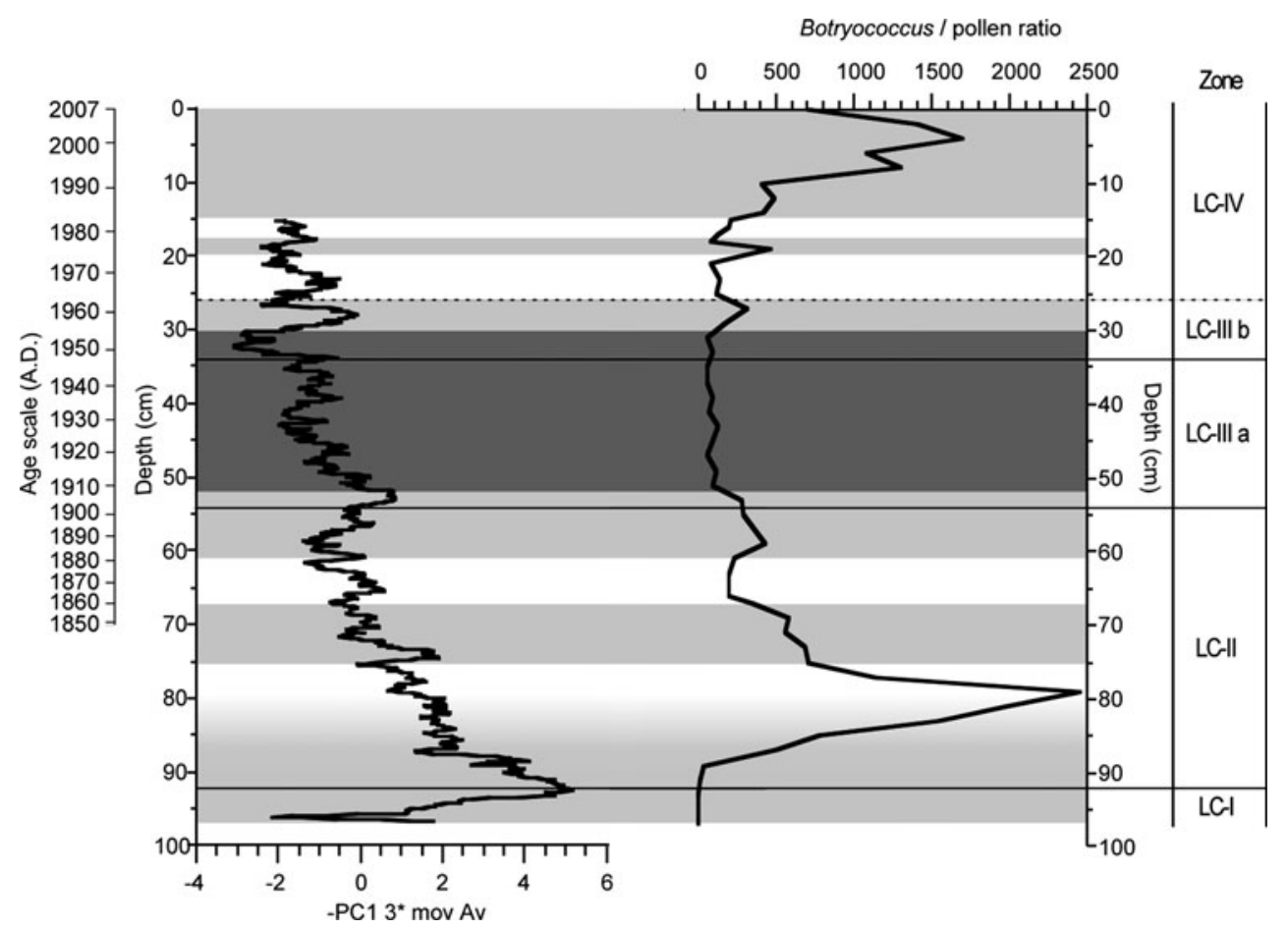

Botryococcus. This is probably caused by single erosion events which did not have a longer lasting impact on the lake level. Interpretation is implemented by the occurrences of Sphagnum as an additional indicator, meaning a higher presence of Sphagnum for periods with lower water level and hence variations in precipitation.

Botryococcus was absent in the bottom sample and started to increase markedly to its highest percentages and concentrations in the lower part of zone LC-II, indicating that the Laguna Campana water level rose quickly after the landslide event. Despite an increasing input of organic material Sphagnum was virtually absent in this period. Therefore the water level must have been high.

The landslide also was probably triggered by very moist conditions, which indicates that the lower part of the record is the wettest. Unfortunately, during the highest occurrence of Botryococcus in LC-II the PC1 signal is overprinted by the vegetation development in the catchment area. Hence, the high but decreasing PC1 values in this depth are probably a response to the developing vegetation cover and only marginally caused by hydrological variations.

After a steep decrease Botryococcus stabilizes. Together with the first re-increase in PC1, this points to still wet conditions. However, with the beginning of Sphagnum development a change to somewhat drier conditions is suggested. The trend of drier conditions continued over the zones LC-IIIa/b, related to the time period of $\sim$ A.D. 19001960. The driest conditions then occurred during the transition between zone LC-IIIa and b around A.D. 1950, when Botryococcus showed its sparsest presence, Sphagnum reached its highest proportions and PC1 yielded its lowest values. At this time the peat moss Sphagnum started to expand and peat bogs arose in the littoral areas.

A marked increase in PC1 values from zone LC- IIIb ( A.D. 1960) onwards reflects a return to more humid conditions probably because of higher precipitation during the last $\sim 50$ years. During the most recent period Botryococcus expanded and Sphagnum was suppressed because of a lake level rise. Although the Botryococcus concentration did not increase markedly in LC-IV, which is probably related to the low sediment compaction, the Botryococcus to pollen ratio gives information about a relative but distinct rise. Additionally, the highest proportions of pteridophyta during this time, including a considerable presence of tree ferns of the genus Cyatheaceae (0-7\%), support wetter climates.

\section{Conclusions}

The multi-proxy approach provided an ample environmental reconstruction combining multiple indicators of human impact and past processes inducing lake genesis and vegetation development. Laguna Campana originated from a shallow landslide which displaced only the uppermost soil horizons. The terminus post quem for the occurrence of the landslide which might have been promoted by anthropogenic impact is A.D. 1470. Humans influenced the study area and its vegetation continuously by slash and burn practices, pastures and deforestation at least for the recorded time 
period and especially during most recent times. Therefore, a dense mountain rainforest could not recuperate in the area. This means that a vegetation structure with diminished biodiversity compared to natural conditions might be similar to the present appearance since the formation of Laguna Campana. An anthropogenic impact can also be concluded from the continuous rise of lead, which can hardly be explained by natural input.

Reconstructed hydrological variations probably caused by variations in precipitation affected riparian vegetation but had no major influence on the vegetation at a greater distance from the lake. However, the wettest conditions probably triggered the landslide and the driest conditions during A.D. 1900-1960 induced local peat bog development in the littoral.

Acknowledgements We wish to sincerely thank Antoine Cleef, Urs Neumeier, Hans Ruppert and Guillaume St-Onge for fruitful discussions. We also acknowledge Fernando Rodriguez and Isabelle Matthias for support during field work. We would like to thank the associate editor Eric C. Grimm and two anonymous reviewers for their comments which improved an earlier version of the manuscript. Torsten Haberzettl was supported by a postdoctoral fellowship scholarship provided by Le Fonds Québécois de la Recherche sur la Nature et les Technologies (FQRNT). The Deutsche Forschungsgemeinschaft (DFG) is thanked for financial support within the research group FOR 816 (Be 2116/8-1). Logistic support was kindly provided by the staff of FOR 816 .

Open Access This article is distributed under the terms of the Creative Commons Attribution Noncommercial License which permits any noncommercial use, distribution, and reproduction in any medium, provided the original author(s) and source are credited.

\section{References}

Abbott MB, Wolfe AP (2003) Intensive pre-incan metallurgy recorded by lake sediments from the Bolivian Andes. Science 301:1893-1895

Aguirre Z, Cabrera O, Sanchez A, Merino B, Maza B (2003) Composición floristica, endemismo y etnonotanica de la vegetación del Sector Oriental, parte baja del Parque Nacional Podocarpus. Lyonia 3:5-14

Baldock JW (1982) Geology of Ecuador-explanatory bulletin of the national geological map of the Republic of Ecuador. Ministerio de Recursos Naturales y Energéticos, Dirección General de Geología y Minas, Quito

Barthlott W, Mutke J, Rafiqpoor D, Kier G, Kreft H (2005) Global centers of vascular plant diversity. Nova Acta Leopold 92:61-83

Batten DJ, Grenfell HR (1996) Botryococcus. In: Jansonius J, MacGregor DC (eds) Palynology: principles and applications. Am Assoc Stratigr Palynol Found, vol 1, Dallas, pp 205-214

Beck E, Bendix J, Kottke I, Makeschin F, Mosandl R (eds) (2008a) Gradients in a tropical mountain ecosystem of Ecuador. Ecol Stud 198. Springer, Berlin, Heidelberg

Beck E, Makeschin F, Haubrich F, Richter M, Bendix J, Valerezo C (2008b) The ecosystem (Reserva Biológica San Francisco). In: Beck E, Bendix J, Kottke I, Makeschin F, Mosandl R (eds)
Gradients in a tropical mountain ecosystem of Ecuador. Ecol Stud 198. Springer, Berlin, Heidelberg, pp 1-13

Beck E, Harting K, Roos K (2008c) Forest clearing by slash and burn. In: Beck E, Bendix J, Kottke I, Makeschin F, Mosandl R (eds) Gradients in a tropical mountain ecosystem of Ecuador. Ecol Stud 198. Springer, Berlin, Heidelberg, pp 371-374

Behling H (1993) Untersuchungen zur spätpleistozänen und holozänen Vegetations- und Klimageschichte der tropischen Küstenwälder und der Araukarienwälder in Santa Catarina (Südbrasilien). Diss Bot 206, Cramer, Berlin/Stuttgart

Bendix J, Rollenbeck R, Richter M, Fabian P, Emck P (2008a) Climate. In: Beck E, Bendix J, Kottke I, Makeschin F, Mosandl $\mathrm{R}$ (eds) Gradients in a tropical mountain ecosystem of Ecuador. Ecol Stud 198. Springer, Berlin, Heidelberg, pp 63-73

Bendix J, Rollenbeck R, Richter M, Fabian P, Emck P, Richter M, Beck E (2008b) Climate variability. In: Beck E, Bendix J, Kottke I, Makeschin F, Mosandl R (eds) Gradients in a tropical mountain ecosystem of Ecuador. Ecol Stud 198. Springer, Berlin, Heidelberg, pp 281-290

Brümmer GW, Gerth J, Herms U (1986) Heavy metal species, mobility and availability in soils. Z Pflanzenernähr Bodenk 149:382-398

Brunschön C, Behling H (2009) Late quaternary vegetation, fire and climate history reconstructed from two cores at Cerro Toledo, Podocarpus National Park, southeastern Ecuadorian Andes. Quat Res 72:388-399

Bush MB, Hanselman JA, Hooghiemstra H (2007) Andean montane forests and climate change. In: Bush MB, Flenley JR (eds) Tropical rainforest responses to climatic change. Springer, Praxis, pp 33-54

Bussmann RW (2001) The montane forests of Reserva Biológica San Francisco (Zamora-Chinchipe, Ecuador)—vegetation zonation and natural vegetation. Die Erde 132:9-25

Bussmann RW, Wilcke W, Richter M (2008) Landslides as important disturbance regimes-causes and regeneration. In: Beck E, Bendix J, Kottke I, Makeschin F, Mosandl R (eds) Gradients in a tropical mountain ecosystem of Ecuador. Ecol Stud 198. Springer, Berlin, Heidelberg, pp 319-330

Charlatchka R, Cambier P (2000) Influence of reducing conditions on solubility of trace metals in contaminated soils. Water Air Soil Pollut 118:143-168

Chuan MC, Shu GY, Liu JC (1996) Solubility of heavy metals in a contaminated soil: effects of redox potential and $\mathrm{pH}$. Water Air Soil Pollut 90:543-556

Cooke CA, Abbott MB, Wolfe AP, Kittleson JL (2007) A millennium of metallurgy recorded by lake sediments from Morococha, Peruvian Andes. Environ Sci Technol 41:3469-3474

Cooke CA, Abbott MB, Wolfe AP (2008) Late-Holocene atmospheric lead deposition in the Peruvian and Bolivian Andes. Holocene 18:353-359

Croudace IW, Rindby A, Rothwell RG (2005) ITRAX: description and evaluation of a new X-ray core scanner. In: Rothwell RG (ed) New techniques in sediment core analysis. Geol Soc, London, pp 51-63

Davis OK (1999) Pollen analysis of Tulare Lake, California: Great Basin-like vegetation in Central California during the full-glacial and early Holocene. Rev Palaeobot Palynol 107:249-257

Dorronsoro C, Martin F, Ortiz I, Garcia I, Simon M, Fernandez E, Aguilar J, Fernandez J (2002) Migration of trace elements from pyrite tailings in carbonate soils. J Environ Qual 31:829-835

Emck P (2007) A climatology of south Ecuador-with special focus on the major Andean Ridge as Atlantic-Pacific Climate Divide. Dissertation, Universität Erlangen-Nürnberg

Fægri K, Iversen J (1989) Textbook of pollen analysis, 4th edn. Wiley, Chichester 
FAO (2006) Global forest resources assessment 2005, Progress towards sustainable forest management. Food and Agricultural Organization of the United Nations, Rome

Gradstein SR, Kessler M, Lehnert M, Abiy M, Homeier J, Mandl N, Makeschin F, Richter M (2008) Vegetation, climate, and soil of the unique Purdiaea forest of Southern Ecuador. Ecotropica $14: 15-26$

Grimm EC (1987) CONISS: a Fortran 77 program for stratigraphically constrained cluster analysis by the method of the incremental sum of squares. Comput Geosci 13:13-35

Grimm EC (1991) Tilia v. 2.0.b.4. Illinois State Museum, Research and Collections Center

Grimm EC (2004) Tilia graph v. 2.0.2. Illinois State Museum, Research and Collections Center

Guariguata MR (1990) Landslide disturbance and forest regeneration in the upper Luquillo mountains of Puerto Rico. J Ecol 78:814 832

Guffroy J (2004) Catamayo precolombino, investigaciones arquelogicas en la provincial de Loja (Ecuador). IRD editions, Paris

Günter S, Stimm B, Cabrera M, Diaz ML, Lojan M, Ordonez E, Richter M, Weber M (2008) Tree phenology in montane forests of southern Ecuador can be explained by precipitation, radiation and photoperiodic control. J Trop Ecol 24:247-258

Guyard H, Chapron E, St-Onge G, Anselmetti FS, Arnaud F, Magand O, Francus P, Mélières MA (2007) High-altitude varve records of abrupt environmental changes and mining activity over the last 4000 years in the Western French Alps (Lake Bramant, Grandes Rousses Massif). Quat Sci Rev 26:2644-2660

Haberzettl T, Fey M, Lücke A, Maidana N, Mayr C, Ohlendorf C, Schäbitz F, Schleser GH, Wille M, Zolitschka B (2005) Climatically induced lake level changes during the last two millennia as reflected in sediments of Laguna Potrok Aike, southern Patagonia (Santa Cruz, Argentina). J Paleolimnol 33:283-302

Haberzettl T, Wille M, Fey M, Janssen S, Lücke A, Mayr C, Ohlendorf C, Schäbitz F, Schleser G, Zolitschka B (2006) Environmental change and fire history of southern Patagonia (Argentina) during the last five centuries. Quat Int 158:72-82

Haberzettl T, Corbella H, Fey M, Janssen S, Lücke A, Mayr C, Ohlendorf C, Schäbitz F, Schleser GH, Wille M, Wulf S, Zolitschka B (2007) Lateglacial and Holocene wet-dry cycles in southern Patagonia: chronology, sedimentology and geochemistry of a lacustrine record from Laguna Potrok Aike, Argentina. Holocene 17:297-310

Haberzettl T, Kück B, Wulf S, Anselmetti F, Ariztegui D, Corbella H, Fey M, Janssen S, Lücke A, Mayr C, Ohlendorf C, Schäbitz F, Schleser GH, Wille M, Zolitschka B (2008) Hydrological variability in southeastern Patagonia and explosive volcanic activity in the southern Andean Cordillera during Oxygen Isotope Stage 3 and the Holocene inferred from lake sediments of Laguna Potrok Aike, Argentina. Palaeogeogr Palaeoclimatol Palaeoecol 259:213-229

Hettwer K, Deicke M, Ruppert H (2003) Fens in Karst SinkholesArchives for Long Lasting 'Immission' Chronologies. Water Air Soil Pollut 149:363-384

Hiller D, Brümmer GW (1991) Elektronenstrahlanalysen zur Erfassung der Schwermetallbindungsformen in Böden unterschiedlicher Schwermetallbelastung. Mitt Dt Bodenkdl Ges 66:10851088

Homeier J, Werner FA (2008) Spermatophyta. In: Liede-Schumann S, Breckle SW (eds) Provisional checklists of flora and fauna of the San Francisco valley and its surroundings, Southern Ecuador. Ecotrop Monogr 4, pp 15-59

Homeier J, Werner FA, Gradstein SR, Breckle S-W, Richter M (2008) Potential vegetation and floristic composition of Andean Forests in South Ecuador, with a Focus on the RBSF. In: Beck E, Bendix
J, Kottke I, Makeschin F, Mosandl R (eds) Gradients in a tropical mountain ecosystem of Ecuador. Ecol Stud 198. Springer, Berlin, Heidelberg, pp 87-100

Hooghiemstra H (1984) Vegetation and climatic history of the High Plain of Bogota, Colombia: a continuous record of the last 3,5 million years. Diss Bot 79, Cramer, Vaduz

INEC (2001) VI censo de población y V de vivienda 2001. Instituto Nacional de Estadistíca y Censos, Quito

Kessler M (1999) Plant species richness and endemism during natural landslide succession in a perhumid montane forest in the Bolivian Andes. Ecotropica 5:123-136

Koinig KA, Shotyk W, Lotter AF, Ohlendorf C, Sturm M (2003) 9000 years of geochemical evolution of lithogenic major and trace elements in the sediment of an alpine lake-the role of climate, vegetation, and land-use history. J Paleolimnol 30:307-320

Lozano PE (2002) Los tipos de bosque en el sur de Ecuador. In: Aguirre Z, Madsen JE, Cotton E, Balsev H (eds) Bótanica Austroecuatoriana. Estudios sobre los recursos vegetales en las provincial de El Oro, Loja y Zamora-Chinchipe. Abya-Yala, Quito, pp 29-49

Lozano P, Delgado T, Aguirre Z (2003) Estado actual de la flora endemica exclusive y su distribucion en el Occidente del Parque Nacional Podocarpus. Funbotanica y Herbario y Jardin Botanico, Loja

Lozano P, Bussmann RW, Küppers M (2005) Landslides as ecosystem disturbance-their implications and importance in South Ecuador. Lyonia 8:67-72

Marchant R, Almeida L, Behling H, Berrio JC, Bush M, Cleef A, Duivenvoorden J, Kappelle M, De Oliveira P, de Oliveira-Filho AT, Lozano-García S, Hooghiemstra H, Ledru M-P, LudlowWiechers B, Markgraf V, Mancini V, Paez M, Prieto A, Rangel O, Salgado-Labouriau ML (2002) Distribution an ecology of parent taxa of pollen lodged within the Latin American Pollen Database. Rev Palaeobot Palynol 121:1-75

McCormac FG, Hogg AG, Blackwell PG, Buck CE, Higham TFG, Reimer PJ (2004) SHCal04 Southern Hemisphere Calibration 0-11.0 cal Kyr BP. Radiocarbon 46:1087-1092

Mirsal IA (2008) Major Types of Soil Pollutants. In: Mirsal IA (ed) Soil pollution. Origin, monitoring \& remediation. Springer, Berlin, pp 117-136

Moar NT (1970) Recent pollen spectra from three localities in the South Island, New Zealand. NZ J Bot 8:210-221

Neill DA (1999) Vegetation. In: Jørgensen PM, León-Yánez S (eds) Catalogue of the vascular plants of Ecuador. Monogr Syst Bot Missouri Bot Gard 75, pp 13-25

Niemann H, Behling H (2008a) Past vegetation and fire dynamics. In: Beck E, Bendix J, Kottke I, Makeschin F, Mosandl R (eds) Gradients in a tropical mountain ecosystem of Ecuador. Ecol Stud 198. Springer, Berlin, Heidelberg, pp 101-111

Niemann H, Behling H (2008b) Late Quaternary vegetation, climate and fire dynamics inferred from the El Tiro record in the southeastern Ecuadorian Andes. J Quat Sci 23:203-212

Niemann H, Behling H (2009) Late Pleistocene and Holocene environmental change inferred from the Cocha Caranga sediment and soil records in the southeastern Ecuadorian Andes. Palaeogeogr Palaeoclimatol Palaeoecol 276:1-14

Niemann H, Behling H (2010) Late Holocene environmental change and human impact inferred from three soil monoliths and the Laguna Zurita multi-proxi record in the southeastern Ecuadorian Andes. Veget Hist Archaeobot 19:1-15

Niemann H, Haberzettl T, Behling H (2009) Holocene climate variability and vegetation dynamics inferred from the $(11700 \mathrm{cal}$. yr BP) Laguna Rabadilla de Vaca sediment record, southeastern Ecuadorian Andes. Holocene 19:307-316

Pohle P (2008) The people settled around Podocarpus National Park. In: Beck E, Bendix J, Kottke I, Makeschin F, Mosandl R (eds) 
Gradients in a tropical mountain ecosystem of Ecuador. Ecol Stud 198. Springer Verlag, Berlin, Heidelberg, pp 25-36

Richardson DM (ed) (2000) Ecology and biogeography of Pinus. University Press, Cambridge

Richter M (2003) Using epiphytes and soil temperature for ecoclimatic interpretations in south Ecuador. Erdkunde 57:161-181

Richter M (2008) Tropical mountain forests-distribution and general features. In: Gradstein SR, Homeier J, Gansert D (eds) The Tropical Mountain Forest-Patterns and Processes in a Biodiversity Hotspot. Biodivers Ecol Ser, vol 2, Universitätsverlag Göttingen, pp 7-24

Richter M, Moreira-Muñoz A (2005) Climatic heterogeneity and plant diversity in southern Ecuador experienced by phytoindication. Rev Peru Biol 12:217-238

Rolland N, Larocque I, Francus P, Pienitz R, Laperriere L (2008) Holocene climate inferred from biological (Diptera: Chironomidae) analyses in a Southampton Island (Nunavut, Canada) lake. Holocene 18:229-241

Salomons W, Förstner U (1984) Metals in the hydrocycle. Springer, Berlin-Heidelberg-New York

Sauer W (1971) Geologie von Ecuador, Mit einem Beitrag: Mineralstoffe von Ecuador von Prof. D. Hannfrit Putzer. Bornträger, Berlin, Stuttgart

Schrumpf M, Guggenberger G, Valarezo C, Zech W (2001) Tropical montane rain forest soils. Development and nutrient status along an altitudinal gradient in the south Ecuadorian Andes. Die Erde 132:43-59

Schubert C, Clapperton CM (1990) Quaternary glaciations in the Northern Andes (Venezuela, Colombia and Ecuador). Quat Sci Rev 9:123-135

Shotyk W, Weiss D, Kramers JD, Frei R, Cheburkin AK, Gloor M, Reese S (2001) Geochemistry of the peat bog at Etang de la Gruère, Jura Mountains, Switzerland, and its record of atmospheric $\mathrm{Pb}$ and lithogenic trace metals ( $\mathrm{Sc}, \mathrm{Ti}, \mathrm{Y}, \mathrm{Zr}$, and REE) since 12, 370 14C yr BP. Geochim Cosmochim Acta 65:2337-2360

Shotyk W, Goodsite ME, Roos-Barraclough F, Givelet N, Le Roux G, Weiss D, Cheburkin AK, Knudsen K, Heinemeier J, Knaap WO, van der Norton SA, Lohse C (2005) Accumulation rates and predominant atmospheric sources of natural and anthropogenic $\mathrm{Hg}$ and $\mathrm{Pb}$ on the Faroe Islands. Geochim Cosmochim Acta 69:1-17

Sigg L, Stumm W (1996) Aquatische Chemie. Teubner, Stuttgart

St-Onge G, Mulder T, Francus P, Long B (2007) Chapter two. continuous physical properties of cored marine sediments. In: Hillaire-Marcel C, de Vernal A (eds) Developments in marine geology, Elsevier, pp 63-98

Stuiver M, Reimer PJ (1993) Extended 14C database and revised CALIB radiocarbon calibration program. Radiocarbon 35:215230

Swedish Environmental Systems (1999) Monitoreo ambiental de las áreas mineras en el sur del Ecuador entre 1996 y 1998. Ministerio de Energía y Minas, Quito, Ecuador

Tarras-Wahlberg NHK, Flachier A, Fredriksson GR, Lane S, Lundberg B, Sangfors O (2000) Environmental impact of small-scale and Artisanal Gold Mining in Southern Ecuador. Ambio 29:484-491

Telford RJ, Heegaard E, Birks HJB (2004) The intercept is a poor estimate of a calibrated radiocarbon age. Holocene 14:296-298

Weng C, Bush MB, Silman MR (2004a) An analysis of modern pollen rain on an elevational gradient in southern Peru. J Trop Ecol 20:113-124

Weng C, Bush MB, Chepstow-Lusty AJ (2004b) Holocene changes of Andean alder (Alnus acuminata) in highland Ecuador and Peru. J Quat Sci 19:685-691

Wilcke W, Valladarez H, Stoyan R, Yasin S, Valarezo C, Zech W (2003) Soil properties on a chronosequence of landslides in montane rain forest, Ecuador. Catena 53:79-95

Wilcke W, Yasin S, Schmitt A, Valarezo C, Zech W (2008) Soils along the altitudinal transect and in catchments. In: Beck E, Bendix J, Kottke I, Makeschin F, Mosandl R (eds) Gradients in a tropical mountain ecosystem of Ecuador. Ecol Stud 198. Springer, Berlin, Heidelberg, pp 75-85

Wunder S (2000) The economics of deforestation: the example of Ecuador. St. Martin, New York 